\title{
Use of MTHFR C677T polymorphism and plasma pharmacokinetics to predict methotrexate toxicity in patients with acute lymphoblastic leukemia
}

\author{
Lobna Ben Mahmoud ${ }^{1, A-F}$, Moez Mdhaffar ${ }^{2, A-D, F}$, Rim Frikha ${ }^{3, A, B}$, Hanen Ghozzi ${ }^{1, A-C}$, \\ Ahmed Hakim ${ }^{1, A}$, Zouheir Sahnoun ${ }^{1, A}$, Moez Elloumi ${ }^{2, A, E}$, Khaled Zeghal ${ }^{1, A, B, E, F}$ \\ ${ }^{1}$ Department of Pharmacology, Faculty of Medicine, University of Sfax, Tunisia \\ 2 Department of Hematology, Hedi Chaker University Hospital, Sfax, Tunisia \\ ${ }^{3}$ Department of Histology, Faculty of Medicine, University of Sfax, Tunisia \\ A - research concept and design; $\mathrm{B}$ - collection and/or assembly of data; $\mathrm{C}$ - data analysis and interpretation; \\ $D$ - writing the article; $E$ - critical revision of the article; $F$ - final approval of the article
}

Address for correspondence

Lobna Ben Mahmoud

E-mail:benmahmoud_lobna@medecinesfax.org

Funding sources

None declared

Conflict of interest

None declared

Received on November 13, 2016

Reviewed on February 19, 2017

Accepted on March 27, 2017

\begin{abstract}
Background. Methotrexate (MTX) is a key component of acute lymphoblastic leukemia (ALL) therapy, but it is associated with serious toxicities in a considerable number of patients.

Objectives. The aim of the current study was to determine which variables were associated with MTX toxicity in children, adolescents and young adults with ALL.

Material and methods. In this prospective study, 35 patients with newly diagnosed ALL, treated according to the 58951 European Organization for Research and Treatment of Cancer - Children's Leukemia Group (EORTC-CLG) protocol, were prospectively enrolled. Toxicity data was collected objectively after each high-dose methotrexate (HD-MTX) course. The risk factors of MTX toxicity were determined using multiple linear regression analysis, with age, gender, immunophenotype, risk group, plasma MTX levels, plasma homocysteine (HCY) levels, and MTHFR C677T included as independent variables.

Results. Twenty-five (71.4\%) patients experienced toxicity on at least 1 course of HD-MTX. In the univariate linear regression, the global toxicity score was associated with a significant rise in plasma $\mathrm{HCY}$ concentrations within $48 \mathrm{~h}$ after MTX administration ( $\beta=0.4 ; R^{2}=0.12 ; p=0.02$ ). In the multiple regression model, the global toxicity score was significantly associated with a higher MTX plasma levels at $48 \mathrm{~h}\left(\beta=0.5 ; R^{2}=0.38\right.$; $p=0.001)$ and (T 677 MTHFR genotype $\left(\beta=0.3 ; R^{2}=0.38 ; p=0.01\right)$.
\end{abstract}

Conclusions. Routine monitoring of plasma MTX concentrations is essential to detect patients at a high risk of MTX toxicity. MTHFR C677T genotyping may be useful for predicting MTX toxicity.

Key words: methotrexate, acute lymphoblastic leukemia, MTHFR C677T polymorphism, toxicity

DOI

$10.17219 /$ acem/69802

Copyright

Copyright by Author(s)

This is an article distributed under the terms of the

Creative Commons Attribution Non-Commercial License

(http://creativecommons.org/licenses/by-nc-nd/4.0/) 


\section{Introduction}

Acute lymphoblastic leukemia (ALL) is the most common pediatric cancer; its survival rate has improved, with 5-year event-free survival (EFS) rates of $70-80 \%$ and overall cure rates of $80 \% .^{1,2}$ Such an improvement in the treatment outcome is largely due to the advances in chemotherapy. Methotrexate (MTX), an antifolate chemotherapeutic agent, plays an important role in the chemotherapy regimen for ALL and has significantly reduced the recurrence rate of ALL in children. ${ }^{3}$

Methotrexate is predominantly taken up into cells via the reduced folate carrier (RFC). ${ }^{4}$ Inside the cell, MTX is converted to its active polyglutamate forms (methotrexate polyglutamates - MTXPGs). ${ }^{5}$ Both MTX and MTXPGs inhibit dihydrofolate reductase, an enzyme that catalyzes the conversion of dihydrofolate to its active form tetrahydrofolate (THF), a substrate of thymidylate synthase (TS), to convert deoxyuridine monophosphate to deoxythymidine-5'-monophosphate, resulting in DNA synthesis. ${ }^{6}$ Tetrahydrofolate deficiency leads to the depletion of intracellular folates, and thereby to decreased synthesis of both purines and pyrimidines, contributing to the inhibition of nucleic acid synthesis and favoring cell death. ${ }^{7}$ Methotrexate polyglutamates can also interfere with methylenetetrahydrofolate reductase (MTHFR), which converts 5,10-methylene-THF to 10-methyl-THF, the major circulating form of folate that provides a methyl group for homocysteine (HCY) methylation to methionine, and channels the methyl group into DNA and protein methylation reactions. ${ }^{6}$

A high-dose methotrexate (HD-MTX) refers to infused MTX in doses of more than $1 \mathrm{~g} / \mathrm{m}^{2} .{ }^{8}$ The use of HD-MTX has shown great benefit in the treatment of childhood ALL and the prevention of extramedullary leukemia, i.e., central nervous system (CNS) leukemia and testicular leukemia. ${ }^{2}$ However, MTX is associated with various toxicities, including severe mucositis, myelosuppression, gastrointestinal toxicity, hepatic toxicity, neurotoxicity, and hematological toxicity, requiring a dose reduction and the interruption of chemotherapy, and subsequently an increased risk of relapse. ${ }^{9}$ Methotrexate-related toxicity remains a common and often unpredictable clinical problem, because of a wide interindividual variation in pharmacokinetics and pharmacodynamics of this drug. ${ }^{8}$

The aim of the current study was, therefore, to determine factors associated with the high risk of MTX toxicity that could help to develop personalized therapies in children, adolescents and young adults with ALL.

\section{Material and methods}

\section{Patients and study design}

From January 2013 to December 2014, 35 patients with newly diagnosed ALL were prospectively enrolled from the Hematology Department of Hedi Chaker University Hospital (Sfax, Tunisia). The diagnosis of ALL was based on morphologic, cytochemical and immunophenotypical criteria.

Patients were selected according to the following inclusion criteria: availability of clinical data, treatment according to the European Organization for Research and Treatment of Cancer - Children's Leukemia Group (EORTC-CLG) 58951 protocol, administration of at least 1 course of intravenous MTX chemotherapy, and no history of other active malignancies requiring a modification of chemotherapy regimen. ${ }^{10}$

Patients were stratified into 4 risk groups (low-risk - LR; average risk 1 - AR1; average risk 2 - AR2, and high-risk - HR) on the basis of their presenting clinical features, the biologic features of their leukemic cells, and their early response to remission-induction treatment. ${ }^{10,11}$

This study was conducted in accordance with the Helsinki Declaration and informed consent was given by all the persons participating in this study.

\section{Treatment}

All patients were treated according to the 58951 EORTCCLG protocol, a Berlin-Frankfurt-Munster-like trial, with treatment phases including induction (IA), consolidation (IB/IB9), CNS prophylaxis without cranial irradiation, late intensification II, and maintenance. ${ }^{11,12}$

According to this protocol, the infusion of HD-MTX was given intravenously in each course at $5 \mathrm{~g} / \mathrm{m}^{2}$ body surface area (BSA) over a 4-hour period. Intravenous hydration and urinary alkalinization were performed 1 day before HD-MTX administration, and continued during and after MTX infusion. Leucovorin rescue $\left(25 \mathrm{mg} / \mathrm{m}^{2}\right)$ was administered every $6 \mathrm{~h}$, starting at $24 \mathrm{~h}$ after the initiation of HD-MTX infusion.

High-dose methotrexate infusions were administered during the interval therapy to all patients, in the induction phase to AR2/HR-ALL, in the consolidation phase to HR-ALL and in the R1-R2 Bloc to HR-ALL.

\section{Plasma methotrexate and homocysteine levels determination}

In each course of HD-MTX, blood samples were collected in ethylenediaminetetraacetic acid (EDTA)-containing tubes at the following times: at 24, 48 and $72 \mathrm{~h}$ from the start of intravenous MTX infusion. Plasma was recuperated by centrifugation at $3000 \mathrm{rpm}$ for $10 \mathrm{~min}$ and was stored at $-20^{\circ} \mathrm{C}$ for the determination of MTX and HCY levels.

Plasma levels of MTX and HCY were determined by a fluorescence polarization immunoassay. Plasma MTX levels were considered high if the concentration was above $10 \mu \mathrm{mol} / \mathrm{L}$ at $24 \mathrm{~h}, 1 \mu \mathrm{mol} / \mathrm{L}$ at $48 \mathrm{~h}$ or $0.1 \mu \mathrm{mol} / \mathrm{L}$ at 72 h. ${ }^{13,14}$ 


\section{MTHFR C677T genotyping}

The MTHFR C677T polymorphism was determined in 28 patients with ALL and 70 healthy subjects taken from the general population ( 35 males and 35 females, age range: 18-29 years). DNA was extracted from peripheral blood samples and polymerase chain reaction-restriction fragment length polymorphism (PCR-RFLP) was performed for the molecular diagnosis of the C677T MTHFR polymorphism. The primers, lengths and restriction enzymes have been described previously. ${ }^{15}$ The $677 \mathrm{C} \rightarrow \mathrm{T}$ base pair substitution creates a Hinf1 restriction site. Then, CC genotype would be reflected by a single band of $265 \mathrm{bp}$, CT genotype by 3 bands of 265, 171, and $94 \mathrm{bp}$, and TT genotype by 2 bands of 171 and $94 \mathrm{bp}$.

\section{Toxicity}

Toxicity data obtained from questionnaires and case records were prospectively collected objectively after each HD-MTX course, in the period from the end of HD-MTX infusion to the next HD-MTX course or until 14 days after HD-MTX infusion.

The toxicity was graded according to the Common Terminology Criteria for Adverse Events (CTCAE, v. 5.0). ${ }^{16}$

According to the modified method of Radtke et al., the global toxicity score for each patient was calculated in our study by adding up the grading of all adverse events that occurred during courses of MTX. ${ }^{17}$ This score integrates both frequency and severity of MTX toxicity. In the study, the higher grade of toxicity in each HD-MTX course was considered.

\section{Statistical analysis}

All statistical analyses were performed using the IBM SPSS Statistics v. 20 software (Chicago, USA). Quantitative variables were expressed as means and standard error of the mean (SEM); they were compared using the t-test or the Wilcoxon-Mann-Whitney test according to the characteristics of the distribution. Qualitative variables were presented as a total number and proportion, and were compared using the $x^{2}$ test or Fisher's exact test according to sample sizes.

To identify the risk factors of MTX toxicity, a multivariate linear regression model was constructed, using variables identified from the univariate analysis, which included age, gender, immunophenotype, risk group, MTX plasma levels, HCY plasma levels, and MTHFR C677T. A stepwise selection was used with probability value of $\mathrm{p}<0.2$ for entry and $\mathrm{p}<0.05$ for removal. For all comparisons, differences were considered statistically significant at $\mathrm{p}<0.05$.

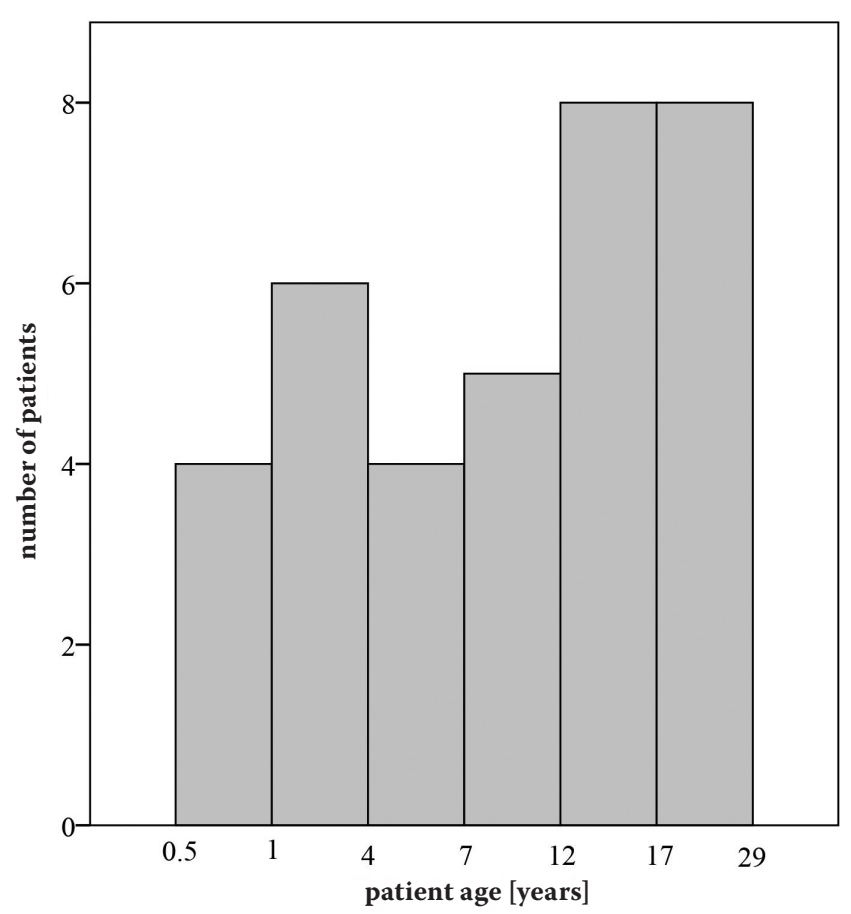

Fig. 1. Age distribution of patients

\section{Results}

\section{Patient characteristics and plasma levels of methotrexate and homocysteine}

A total of 35 patients (21 males and 14 females) with newly diagnosed ALL treated with the 58951 EORTC-CLG protocol were enrolled in this study. The mean patient age at diagnosis was $11.7 \pm 9$ years (median: 10.1 years; range: 0.5-29 years) (Fig. 1). Patients' characteristics were shown in Table 1.

According to risk stratification, 12 patients were from AR1 group, 13 from AR2 group and 10 from HR group. A total of 173 courses of HD-MTX at $5 \mathrm{~g} / \mathrm{m}^{2}$ were administered.

In the study, 168 plasma MTX levels and 125 plasma HCY levels were analyzed. The results of these analyses are presented in Table 1.

Methotrexate levels ranged from 0.9 to $13 \mu \mathrm{mol} / \mathrm{L}$ at $24 \mathrm{~h}$, from 0.02 to $6.7 \mu \mathrm{mol} / \mathrm{L}$ at $48 \mathrm{~h}$ and from 0.01 to $0.9 \mu \mathrm{mol} / \mathrm{L}$ at $72 \mathrm{~h}$. Homocysteine levels ranged from 8 to $19 \mu \mathrm{mol} / \mathrm{L}$ at $24 \mathrm{~h}$, from 5 to $15.5 \mu \mathrm{mol} / \mathrm{L}$ at $48 \mathrm{~h}$ and from 0.13 to $17 \mu \mathrm{mol} / \mathrm{L}$ at $72 \mathrm{~h}$.

\section{High-dose methotrexate-related toxicity}

Of 35 patients, 25 (71.4\%) experienced toxicity on at least 1 course of HD-MTX. The mean of global toxicity score for these patients was $5.1 \pm 2.1$ (range: $1-12$ ). A total of 59 cases of MTX-related toxicity were observed among 173 courses of HD-MTX (on average, 2 cases of toxicity per patient; range: 1-9) (Table 1). 
Table 1. Characteristics of patients, their clinical condition and toxicity experienced

\begin{tabular}{|c|c|c|}
\hline Characteristics of patients & \multicolumn{2}{|c|}{ Total number of patients $(n=35)$} \\
\hline $\begin{array}{l}\text { Age at diagnosis [years], } \\
\text { mean } \pm \text { SEM (min-max) } \\
<10 \text { years, } n(\%) \\
\geq 10 \text { years, } n(\%)\end{array}$ & \multicolumn{2}{|c|}{$\begin{array}{c}11.7 \pm 1.6(0.5-29) \\
17(48.6) \\
18(51.4)\end{array}$} \\
\hline $\begin{array}{l}\text { Gender } \\
\text { male, n (\%) } \\
\text { female, n (\%) }\end{array}$ & \multicolumn{2}{|c|}{$\begin{array}{l}21(60) \\
14(40)\end{array}$} \\
\hline $\begin{array}{l}\text { Immunophenotype } \\
\text { B-ALL, n (\%) } \\
\text { T-ALL, n (\%) }\end{array}$ & \multicolumn{2}{|c|}{$\begin{array}{l}23(65.7) \\
12(34.3)\end{array}$} \\
\hline $\begin{array}{l}\text { Weight }[\mathrm{kg}] \text {, mean } \pm \text { SEM } \\
(\min -\max )\end{array}$ & \multicolumn{2}{|c|}{$\begin{array}{l}41.5 \pm 4 \\
(11-60)\end{array}$} \\
\hline $\begin{array}{l}\text { Height }[\mathrm{cm}] \text {, mean } \pm \text { SEM } \\
\text { (min-max) }\end{array}$ & \multicolumn{2}{|c|}{$\begin{array}{l}138 \pm 5.5 \\
(80-183)\end{array}$} \\
\hline $\mathrm{BSA}\left[\mathrm{m}^{2}\right]$, mean \pm SEM (min-max) & \multicolumn{2}{|c|}{$1.2 \pm 0.1(0.5-2)$} \\
\hline $\begin{array}{l}\text { Risk group } \\
\qquad \begin{array}{l}A R 1, n(\%) \\
A R 2, n(\%) \\
H R, n(\%)\end{array}\end{array}$ & \multicolumn{2}{|c|}{$\begin{array}{l}12(34.3) \\
13(37.1) \\
10(28.6)\end{array}$} \\
\hline MTX-related toxicity & $\begin{array}{l}\text { Total number } \\
\text { of patients } \\
(\mathrm{n}=35)^{*}\end{array}$ & $\begin{array}{l}\text { Total number } \\
\text { of HD-MTX } \\
\text { courses } \\
(n=173)\end{array}$ \\
\hline $\begin{array}{l}\text { Hepatotoxicity, n (\%) } \\
\text { grade } 2 \\
\text { grade } 3 \\
\text { grade } 4\end{array}$ & $\begin{array}{c}13(37.1) \\
7 \\
4 \\
2\end{array}$ & $\begin{array}{c}17(9.8) \\
9 \\
6 \\
2\end{array}$ \\
\hline $\begin{array}{l}\text { Gastrointestinal toxicity, n (\%) } \\
\text { grade } 1 \\
\text { grade } 2 \\
\text { grade } 3\end{array}$ & $\begin{array}{c}10(28.6) \\
1 \\
3 \\
7\end{array}$ & $\begin{array}{c}17(9.8) \\
1 \\
9 \\
7\end{array}$ \\
\hline $\begin{array}{l}\text { Mucositis, n (\%) } \\
\text { grade } 3 \\
\text { grade } 4\end{array}$ & $\begin{array}{c}6(17.1) \\
3 \\
4\end{array}$ & $\begin{array}{c}8(4.6) \\
3 \\
5\end{array}$ \\
\hline $\begin{array}{l}\text { Neurotoxicity, n (\%) } \\
\text { grade } 1 \\
\text { grade } 3 \\
\text { grade } 4\end{array}$ & $\begin{array}{c}3(8.6) \\
1 \\
2 \\
2\end{array}$ & $\begin{array}{c}5(2.9) \\
1 \\
2 \\
2\end{array}$ \\
\hline $\begin{array}{l}\text { Skin toxicity, n (\%) } \\
\text { grade } 1 \\
\text { grade } 2 \\
\text { grade } 3\end{array}$ & $\begin{array}{c}6(17.1) \\
1 \\
1 \\
4\end{array}$ & $\begin{array}{c}6(3.4) \\
1 \\
1 \\
4\end{array}$ \\
\hline $\begin{array}{l}\text { Hematotoxicity, n (\%) } \\
\text { grade } 1 \\
\text { grade } 4\end{array}$ & $\begin{array}{c}2(2.7) \\
1 \\
1\end{array}$ & $\begin{array}{c}2(1.1) \\
1 \\
1\end{array}$ \\
\hline $\begin{array}{l}\text { Renal toxicity, n (\%) } \\
\text { grade } 2\end{array}$ & $\begin{array}{c}1(2.8) \\
1\end{array}$ & $\begin{array}{c}1(0.6) \\
1\end{array}$ \\
\hline Phlebitis, n (\%) & $2(2.7)$ & $3(1.7)$ \\
\hline Plasma MTX levels $[\mu \mathrm{M}]$ & \multicolumn{2}{|c|}{ Total number $(n=168)$} \\
\hline $\begin{array}{l}24 h(n=66), \text { mean } \pm \text { SEM, } \\
48 h(n=54), \text { mean } \pm \text { SEM } \\
72 h(n=48), \text { mean } \pm \text { SEM }\end{array}$ & \multicolumn{2}{|c|}{$\begin{array}{l}5.6 \pm 0.6 \\
1.3 \pm 0.3 \\
0.1 \pm 0.02\end{array}$} \\
\hline Plasma HCY levels $[\mu \mathrm{M}]$ & \multicolumn{2}{|c|}{ Total number $(n=125)$} \\
\hline $\begin{array}{l}24 h(n=49), \text { mean } \pm \text { SEM } \\
48 h(n=48), \text { mean } \pm \text { SEM } \\
72 h(n=28), \text { mean } \pm \text { SEM }\end{array}$ & \multicolumn{2}{|c|}{$\begin{array}{c}12.2 \pm 30.6 \\
10 \pm 0.5 \\
8 \pm 0.8\end{array}$} \\
\hline
\end{tabular}

BSA - body surface area; AR - average risk; HR - high risk; MTX - methotrexate; HCY - homocysteine; HD-MTX - high-dose methotrexate; SEM standard error of the mean; * the upper grade of toxicity in each HD-MTX course was considered.
Hepatic and gastrointestinal toxicities were the most frequently observed toxicities, accounting for $57.6 \%$ of the total number of observed toxicities. Methotrexate-induced hepatotoxicity was expressed by elevated aspartate aminotransferase/alanine aminotransferase (ASAT/ALAT). There were 55 cases of toxicity (93.2\%) with grade 2 or greater, and only 4 cases of toxicity with grade 1 (6.8\%) (Table 1$)$.

\section{Plasma methotrexate levels and methotrexate-related toxicity}

The univariate linear regression revealed that the global toxicity score was significantly associated with plasma levels of MTX at $24 \mathrm{~h}\left(\beta=0.64 ; \mathrm{R}^{2}=0.41 ; \mathrm{p}=0.001\right)$, $48 \mathrm{~h}\left(\beta=0.43 ; \mathrm{R}^{2}=0.19 ; \mathrm{p}=0.01\right)$ and $72 \mathrm{~h}(\beta=0.37$; $\mathrm{R}^{2}=0.14 ; \mathrm{p}=0.03$ ) (Table 2).

Methotrexate plasma levels $\geq 10 \mu \mathrm{mol} / \mathrm{L}$ at $24 \mathrm{~h}$ were significantly associated with higher HCY plasma levels at 24 and $48 \mathrm{~h}$ after the initiation of MTX infusion (Table 3).

Table 2. Risk factors for MTX toxicity (univariate linear regression)

\begin{tabular}{|c|c|c|c|c|}
\hline Patients & $\begin{array}{l}\text { p-value } \\
\text { (Fisher's } \\
\text { exact test, } \\
\text { global) }\end{array}$ & $\beta$ & $\beta 0$ & $\mathrm{R}^{2}(\%)$ \\
\hline Age at diagnosis [years] & 0.45 & 0.13 & 3.1 & 1.7 \\
\hline Gender ( $\mathrm{M}$ vs F) & 0.78 & 0.04 & 3.1 & 0.2 \\
\hline Immunophenotype (T vs B) & 0.67 & -0.07 & 4.5 & 0.6 \\
\hline Weight & 0.37 & 0.15 & 2.7 & 2.4 \\
\hline Height & 0.4 & 0.1 & 1.5 & 2.1 \\
\hline BSA & 0.35 & 0.16 & 2.3 & 2.6 \\
\hline Risk group (AR1, AR2, HR) & 0.14 & 0.2 & 0.5 & 0.6 \\
\hline $\begin{array}{l}\text { Plasma levels of MTX } \\
24 \mathrm{~h} \\
48 \mathrm{~h} \\
72 \mathrm{~h}\end{array}$ & $\begin{array}{l}10^{-3} \\
0.01 \\
0.03\end{array}$ & $\begin{array}{l}0.64 \\
0.43 \\
0.37\end{array}$ & $\begin{array}{l}0.9 \\
2.4 \\
2.5\end{array}$ & $\begin{array}{r}41.1 \\
19.1 \\
14.3\end{array}$ \\
\hline $\begin{array}{l}\text { Plasma levels of HCY } \\
24 \mathrm{~h} \\
48 \mathrm{~h} \\
72 \mathrm{~h}\end{array}$ & $\begin{array}{l}0.14 \\
0.02 \\
0.18\end{array}$ & $\begin{array}{l}0.28 \\
0.4 \\
-0.31\end{array}$ & $\begin{array}{l}2.4 \\
2.1 \\
1.3\end{array}$ & $\begin{array}{r}4.5 \\
12.8 \\
4.8\end{array}$ \\
\hline MTHFR C677T (CT Vs CC) & 0.02 & 0.4 & 1.8 & 19 \\
\hline
\end{tabular}

BSA - body surface area; MTX - methotrexate; HCY - homocysteine; $\mathrm{M}$ - males; $\mathrm{F}$ - females; $\mathrm{AR}$ - average risk; $\mathrm{HR}$ - high risk; $\beta$ - regression coefficient; $\beta 0$ - intercept coefficient.

As shown in Table 3, the global toxicity score was significantly correlated with MTX levels $>10 \mu \mathrm{mol} / \mathrm{L}$ at $24 \mathrm{~h}$, $1 \mu \mathrm{mol} / \mathrm{L}$ at $48 \mathrm{~h}$ and $0.1 \mu \mathrm{mol} / \mathrm{L}$ at $72 \mathrm{~h}$. Gastrointestinal and skin toxicity were significantly associated with high MTX plasma levels 48 and $72 \mathrm{~h}$ after MTX infusion (Table 3).

\section{Plasma homocysteine levels and methotrexate-related toxicity}

The univariate linear regression revealed a positive correlation between global toxicity score and plasma $\mathrm{HCY}$ 
Table 3. Correlation between folate pathway and MTX toxicity

\begin{tabular}{|c|c|c|c|c|c|c|c|c|}
\hline \multirow{3}{*}{ Plasma HCY and MTX toxicity } & \multicolumn{6}{|c|}{ Plasma MTX } & \multirow{2}{*}{\multicolumn{2}{|c|}{ MTHFR }} \\
\hline & \multicolumn{2}{|c|}{ at $24 \mathrm{~h}(\mathrm{n}=31)$} & \multicolumn{2}{|c|}{ at $48 \mathrm{~h}(\mathrm{n}=32)$} & \multicolumn{2}{|c|}{ at $72 \mathrm{~h}(\mathrm{n}=30)$} & & \\
\hline & $\begin{array}{l}<10 \mu M \\
(n=25)\end{array}$ & $\begin{array}{c}\geq 10 \mu \mathrm{M} \\
(\mathrm{n}=6)\end{array}$ & $\begin{array}{c}<1 \mu M \\
(n=18)\end{array}$ & $\begin{array}{c}\geq 1 \mu \mathrm{M} \\
(\mathrm{n}=14)\end{array}$ & $\begin{array}{l}<0.1 \mu M \\
(n=19)\end{array}$ & $\begin{array}{l}\geq 0.1 \mu \mathrm{M} \\
(\mathrm{n}=11)\end{array}$ & $\underset{\substack{C C \\
(n=22)}}{ }$ & $\mathrm{CT}(\mathrm{n}=6)$ \\
\hline Plasma HCY at $24 \mathrm{~h}[\mu \mathrm{M}]$, mean \pm SEM & $11.6 \pm 0.6$ & $15 \pm 1.8^{*}$ & $12.2 \pm 0.8$ & $12.3 \pm 1.3$ & $12 \pm 0.7$ & $13 \pm 1.3$ & $12 \pm 0.7$ & $13.3 \pm 2$ \\
\hline Plasma HCY at $48 \mathrm{~h}[\mu \mathrm{M}]$, mean \pm SEM & $8.8 \pm 0.5$ & $11.6 \pm 0.9^{*}$ & $9.2 \pm 0.6$ & $10 \pm 0.7$ & $9.1 \pm 0.6$ & $10 \pm 0.8$ & $8.2 \pm 0.5$ & $10 \pm 0.9$ \\
\hline Plasma HCY at $72 \mathrm{~h}[\mu \mathrm{M}]$, mean \pm SEM & $8.5 \pm 0.8$ & $6.3 \pm 4$ & $9.6 \pm 1$ & $7 \pm 1.1$ & $8.7 \pm 1$ & $8.2 \pm 1.7$ & $8.1 \pm 0.9$ & $5.9 \pm 3$ \\
\hline Global toxicity, mean \pm SEM & $2.5 \pm 0.5$ & $7.5 \pm 1.6^{*}$ & $1.6 \pm 0.5$ & $6.3 \pm 0.7^{*}$ & $1.5 \pm 0.4$ & $6.7 \pm 0.8^{*}$ & $2.5 \pm 0.6$ & $6.1 \pm 1.7^{*}$ \\
\hline Gastrointestinal toxicity (n) & 8 & 3 & 4 & $9^{+}$ & 4 & $7^{+}$ & 8 & 3 \\
\hline Mucositis (n) & 2 & 2 & 1 & 4 & 1 & $5^{\dagger}$ & 2 & 1 \\
\hline Nausea/vomiting/diarrhea (n) & 4 & 3 & 2 & $7^{+}$ & 3 & 4 & 4 & 3 \\
\hline Abdominal pain (n) & 3 & 1 & 2 & 3 & 1 & 3 & 4 & 1 \\
\hline Liver toxicity (n) & 6 & 5 & 6 & 6 & 6 & 6 & 5 & 4 \\
\hline Renal toxicity (n) & 0 & 1 & 0 & 1 & 0 & 1 & 0 & 1 \\
\hline Neurotoxicity (n) & 2 & 2 & 1 & 3 & 1 & 1 & 1 & 2 \\
\hline Seizure (n) & 1 & 0 & 0 & 1 & 0 & 0 & 1 & 0 \\
\hline Somnolence (n) & 1 & 0 & 1 & 0 & 1 & 0 & 0 & 1 \\
\hline Paralysis (n) & 0 & 1 & 0 & 1 & 0 & 1 & - & - \\
\hline Agitation (n) & 1 & 0 & 0 & 1 & 0 & 0 & 1 & 0 \\
\hline Anxiety/mood disorder (n) & 0 & 1 & 0 & 1 & 0 & 0 & 0 & 1 \\
\hline Skin toxicity (n) & 4 & 3 & 1 & $6^{+}$ & 2 & $5^{+}$ & 3 & 2 \\
\hline Hematotoxicity (n) & 2 & 0 & 2 & 0 & 1 & 1 & 2 & 0 \\
\hline Thrombocytopenia (n) & 1 & 0 & 1 & 0 & 1 & 0 & 1 & 0 \\
\hline Hemorrhage (n) & 1 & 0 & 1 & 0 & 0 & 1 & 1 & 0 \\
\hline Phlebitis (n) & 1 & 1 & 1 & 1 & 1 & 1 & 1 & 1 \\
\hline
\end{tabular}

MTX - methotrexate; HCY - homocysteine; SEM - standard error of the mean; * statistically significant differences between groups estimated using Mann-Whitney $\mathrm{U}$ test; ${ }^{\dagger}$ statistically significant differences between groups estimated using Fisher's exact test.
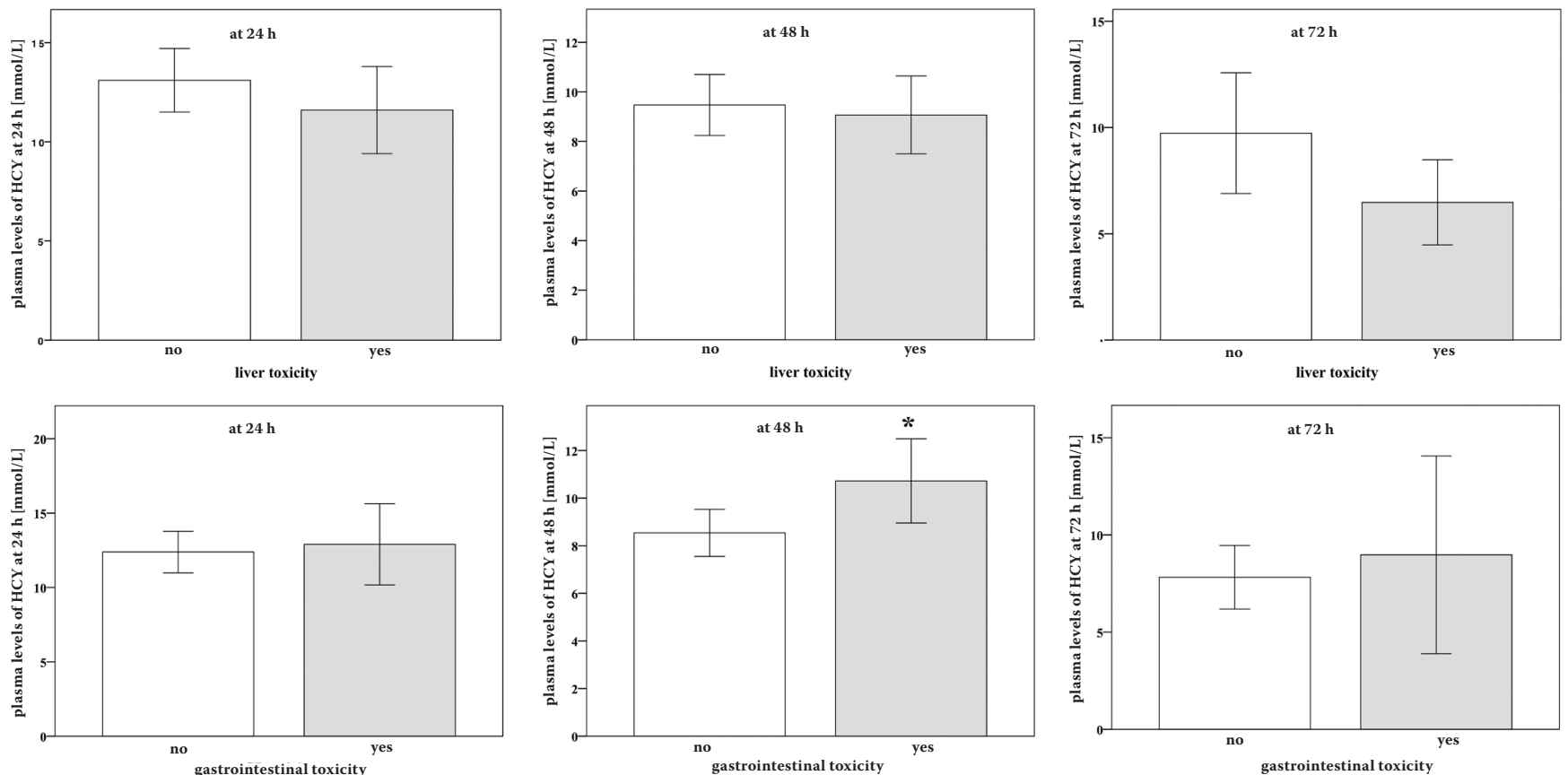

Fig. 2. Association of liver toxicity and gastrointestinal toxicity with plasma homocysteine levels Each column represents mean with standard deviation ( \pm SD); $\mathrm{HCY}$ - homocysteine; ${ }^{*} \mathrm{p}=0.02$. 
levels within $48 \mathrm{~h}$ after MTX administration $(\beta=0.4$; $\mathrm{R}^{2}=0.12 ; \mathrm{p}=0.02$ ) (Table 2). Figure 2 shows that $\mathrm{HCY}$ plasma levels at $48 \mathrm{~h}$ were significantly higher in patients with gastrointestinal toxicity $(\mathrm{p}=0.02)$.

\section{Gene polymorphisms and methotrexate-related toxicity}

The MTHFR C677T polymorphism was in Hardy-Weinberg equilibrium. MTHFR $677 C>T$ was of the wild type (CC) in 22 patients (78.6\%) and 70 controls (100\%), and heterozygous (CT) in 6 (21.4\%).

The influence of this polymorphism on MTX toxicity was analyzed in 28 patients with ALL included in this study. The mean global toxicity score was significantly higher in MTHFR 677 CT genotype than in wild genotype ( $\mathrm{p}=0.02)$ (Tables 2,3).

There was no significant association between MTHFR $677 C>T$ polymorphism and plasma MTX levels.

\section{Risk factors for methotrexate toxicity}

In a multiple regression model, the global toxicity score was significantly associated with 2 variables: higher MTX plasma levels at $48 \mathrm{~h}(\geq 1 \mu \mathrm{mol} / \mathrm{L})\left(\beta=0.5 ; \mathrm{R}^{2}=0.38\right.$; $\mathrm{p}=0.001)$ and CT 677 MTHFR genotype $\left(\beta=0.3 ; \mathrm{R}^{2}=0.38\right.$; $\mathrm{p}=0.01)$.

\section{Discussion}

Intravenous HD-MTX is a key component in the therapy of ALL. ${ }^{3}$ However, despite leucovorin rescue with hydration and urinary alkalinization, MTX is associated with serious toxicities in a considerable number of patients. ${ }^{15}$ This could lead to the interruption of treatment, which may increase relapse risk.

This study identified several clinical variables that influence MTX toxicity in patients with ALL treated according to the EORTC-CLG 58951 protocol. We used the global toxicity score that integrates both severity and frequency of MTX toxicity during 173 HD-MTX courses.

One of the major limitations of the current study was the small sample size; studies with a greater number of patients would be necessary to confirm our results. However, a homogenous diagnosis, a standardized treatment protocol followed by all patients, objective and well-recorded toxicity data make the results credible.

High-dose methotrexate was associated with toxicities in the majority of patients included in this study (71.1\%). Consistent with previous studies, we found that the most common side effects following HD-MTX therapy were hepato-, skin and gastrointestinal toxicity, particularly the oral mucositis. ${ }^{18}$

This toxicity is unpredictable because of large inter-patient variability in the pharmacokinetics and pharmacodynamics of this drug, even with the same treatment protocol. 5,7,18 The mechanism of MTX-induced toxicity could be mainly explained by an inhibition of normal cells and tissue adjacent to the target abnormal cells. ${ }^{8}$

In this study, acute MTX-induced hepatotoxicity was expressed by elevated ASAT/ALAT and was observed in $37.1 \%$ of patients. The pathophysiology of this side effect remains unclear. Holmboe et al. suggested that 7-OHMTX, a main metabolite of MTX, was involved in the development of HD-MTX hepatic toxicity in patients with osteosarcoma treated with HD-MTX. ${ }^{19}$

Oral mucositis was the most severe MTX-related toxicity observed in this study. Considerable effort has been expended to identify the etiopathophysiology of this side effect. ${ }^{20,21}$ Pico et al. reported that MTX may be secreted in the saliva, leading to increased direct mucotoxicity. ${ }^{22}$

In the present study, we analyzed the relation between MTX pharmacokinetics and MTX-related toxicities during HD-MTX courses. In multiple linear regression analysis, we found that plasma MTX levels at $48 \mathrm{~h}$ were significantly correlated with the global toxicity score. Currently, few studies among patients with ALL have reported that the plasma levels of MTX may influence the risk of MTX toxicity. ${ }^{23-25}$

In the current study, acute MTX-induced hepatotoxicity, which was the most common side effect, was not associated with plasma MTX levels. This can be explained by the fact that the small number of children in this study could influence its power to detect a significant association.

We found that the risk of oral mucositis was significantly associated with high MTX plasma levels $72 \mathrm{~h}$ after drug infusion (Table 3). This finding is consistent with those of Cheng, who revealed that $64 \%$ of children with oral mucositis had plasma MTX levels above the defined upper limit of the expected profile at 66 h. ${ }^{25}$ It is rather remarkable to find a higher frequency of nausea/vomiting episodes in patients with high MTX plasma levels at $48 \mathrm{~h}$. Although the exact mechanism is unclear, it was reported that nausea/vomiting can lead to dehydration, causing decreased glomerular filtration rates, and thus limited renal clearance of MTX. ${ }^{24}$

It was also reported that MTX-related toxicity might be explained through the disruption of folate homeostasis. ${ }^{26}$ In this study, we determined the plasma HCY levels, since it was considered a sensitive marker of deficient folate homeostasis. ${ }^{27}$

We found that elevated levels of HCY were associated with higher MTX plasma levels at $24 \mathrm{~h}$, which is consistent with the previous study. ${ }^{28}$ This can be explained by the interference of MTX with the metabolism of HCY by reducing the level of 5-methyl-THF, which serves as the donor of the methyl group for the methylation of HCY to methionine. As a result, the levels of HCY increase, whereas the levels of methionine decrease. ${ }^{29}$

Moreover, we found that global toxicity score, particularly gastrointestinal toxicity, was associated with 
a significant rise in plasma HCY levels within $48 \mathrm{~h}$ after MTX administration. Although a strong association between blood levels of $\mathrm{HCY}$ and the risk of the development of CNS disorders has been shown, there are few studies reporting such an association with gastrointestinal toxicity. ${ }^{30-32}$ Hyperhomocysteinemia may induce cell damage through a number of complex mechanisms, including interference with the methylation process and disturbance of oxidative stress balance. ${ }^{33-35}$

Therefore, an increased level of HCY might be considered a sensitive marker of MTX toxicity.

The MTHFR gene is located at the end of the short arm of chromosome 1 (1p36.3), and the encoded protein, $M T H$ $F R$, is a key enzyme in folate metabolism. ${ }^{36,37}$ The C677T single nucleotide polymorphism (SNP) is the most studied polymorphism in the MTHFR gene and results in an alanine-to-valine substitution at codon 222. Its variant alleles cause a substantial reduction of the MTHFR enzyme activity in vitro compared with the wild type allele. ${ }^{38}$ People with a heterozygous MTHFR 677 CT genotype have 60\% enzyme activity compared with those with the wild-type allele. ${ }^{39}$ In the present study, we investigated whether there exists an influence of MTHFR C677T polymorphism on MTX-related toxicity. We found a significantly increased risk of MTX-related toxicity in patients with 677CT genotype compared with the wild genotype 677CC. This result was consistent with previous studies. ${ }^{40,41} \mathrm{~A}$ meta-analysis of studies concerning the toxicity of low-dose MTX (10-15 mg/week) in rheumatoid arthritis suggested that $\mathrm{C677T}$ polymorphism was significantly associated with increased toxicity. ${ }^{40}$ Another meta-analysis in ALL patients, including 21 articles published before September 2010, supported this association and suggested that the $677 \mathrm{~T}$ allele serves as a toxicity predictor during treatment with MTX. ${ }^{41}$

In conclusion, the results of our study suggest that routine monitoring of plasma MTX levels during 48-72 h is essential to detect patients at a high risk of developing toxicity and to adjust leucovorin rescue and hydration. Moreover, we suggest that MTHFR C677T genotyping may be useful for predicting MTX toxicity. Future studies with large sample sizes should be undertaken to verify current findings, which may provide further biomarkers of treatment efficacy and toxicity in patients with ALL.

\section{References}

1. Pui CH, Evans WE. Treatment of acute lymphoblastic leukemia. NEngl J Med. 2006;354:166-178.

2. Pui $\mathrm{CH}$, Relling MV, Downing JR. Acute lymphoblastic leukemia. NEngl J Med. 2004;350:1535-1548.

3. de Beaumais $T A$, Jacqz-Aigrain E. Intracellular disposition of methotrexate in acute lymphoblastic leukemia in children. Curr Drug Metab. 2012;13:822-834.

4. Assaraf YG. Molecular basis of antifolate resistance. Cancer Metastasis Rev. 2007;26:153-181.

5. Mikkelsen TS, Thorn CF, Yang JJ, et al. PharmGKB summary: Methotrexate pathway. Pharmacogenet Genomics. 2011;21:679-686.

6. Bagley PJ, Selhub J. A common mutation in the methylenetetrahydrofolate reductase gene is associated with an accumulation of for- mylated tetrahydrofolates in red blood cells. Proc Natl Acad Sci USA. 1998;95:13217-13220.

7. Ongaro A, De Mattei M, Della Porta MG, et al. Gene polymorphisms in folate metabolizing enzymes in adult acute lymphoblastic leukemia: Effects on methotrexate-related toxicity and survival. Haematologica. 2009;94:1391-1398.

8. Treon SP, Chabner BA. Concepts in use of high-dose methotrexate therapy. Clin Chem. 1996;42:1322-1329.

9. Tantawy AA, El-Bostany EA, Adly AA, et al. Methylene tetrahydrofolate reductase gene polymorphism in Egyptian children with acute lymphoblastic leukemia. Blood Coagul Fibrinolysis. 2010;21:28-34.

10. Vilmer E, Suciu S, Ferster A, et al.; Children Leukemia Cooperative Group. Long-term results of three randomized trials (58831, 58832, 58881) in childhood acute lymphoblastic leukemia: A CLCG-EORTC report. Leukemia. 2000;14:2257-2266.

11. De Moerloose B, Suciu S, Bertrand Y, et al. Improved outcome with pulses of vincristine and corticosteroids in continuation therapy of children with average risk acute lymphoblastic leukemia (ALL) and lymphoblastic non-Hodgkin lymphoma (NHL): Report of the EORTC randomized phase 3 trial 58951. Blood. 2010;116:36-44.

12. Domenech C, Suciu S, De Moerloose B, etal. Dexamethasone $\left(6 \mathrm{mg} / \mathrm{m}^{2} /\right.$ day) and prednisolone $\left(60 \mathrm{mg} / \mathrm{m}^{2} /\right.$ day $)$ were equally effective as induction therapy for childhood acute lymphoblastic leukemia in the EORTC CLG 58951 randomized trial. Haematologica. 2014;99:1220-1227.

13. Nirenberg A, Mosende C, Mehta BM, Gisolfi AL, Rosen G. Highdose methotrexate with citrovorum factor rescue: Predictive value of serum methotrexate concentrations and corrective measures to avert toxicity. Cancer Treat Rep. 1977;61:779-783.

14. Paci A, Veal G, Bardin C, et al. Review of therapeutic drug monitoring of anticancer drugs. Part 1: Cytotoxics. Eur J Cancer. 2014;50:2010-2019.

15. Ayad MW, El Naggar AA, El Naggar M. MTHFR C677T polymorphism: Association with lymphoid neoplasm and effect on methotrexate therapy. Eur J Haematol. 2014;93:63-69.

16. National Institutes of Health. National Cancer Institute CTEP CTCAE v. 5.0. 2016. http://ctep.cancer.gov/. Accessed November 27, 2017.

17. Radtke S, Zolk O, Renner B, et al. Germline genetic variations in methotrexate candidate genes are associated with pharmacokinetics, toxicity, and outcome in childhood acute lymphoblastic leukemia. Blood. 2013;121:5145-5153.

18. Schmiegelow K. Advances in individual prediction of methotrexate toxicity: A review. Br J Haematol. 2009;146:489-503.

19. Holmboe L, Andersen AM, Mørkrid L, Slørdal L, Hall KS. High dose methotrexate chemotherapy: Pharmacokinetics, folate and toxicity in osteosarcoma patients. Br J Clin Pharmacol. 2012;73:106-114.

20. Sonis ST. Mucositis as a biological process: A new hypothesis for the development of chemotherapy-induced stomatotoxicity. Oral Oncol. 1998;34:39-43.

21. Sonis ST, Elting LS, Keefe D, et al.; Mucositis Study Section of the Multinational Association for Supportive Care in Cancer, International Society for Oral Oncology. Perspectives on cancer therapy-induced mucosal injury: Pathogenesis, measurement, epidemiology, and consequences for patients. Cancer. 2004;100:1995-2025.

22. Pico JL, Avila-Garavito A, Naccache P. Mucositis: Its occurrence, consequences, and treatment in the oncology setting. Oncologist. 1998;3: 446-451.

23. Rask C, Albertioni F, Bentzen SM, Schroeder H, Peterson C. Clinical and pharmacokinetic risk factors for high-dose methotrexate-induced toxicity in children with acute lymphoblastic leukemia - a logistic regression analysis. Acta Oncol. 1998;37:277-284.

24. Relling MV, Fairclough $D$, Ayers $D$, et al. Patient characteristics associated with high-risk methotrexate concentrations and toxicity. J Clin Oncol. 1994;12:1667-1672.

25. Cheng KK. Association of plasma methotrexate, neutropenia, hepatic dysfunction, nausea/vomiting and oral mucositis in children with cancer. Eur J Cancer Care (Engl). 2008;17:306-311.

26. Cole PD, Beckwith KA, Vijayanathan V, Roychowdhury S, Smith AK, Kamen BA. Folate homeostasis in cerebrospinal fluid during therapy for acute lymphoblastic leukemia. Pediatr Neurol. 2009;40:34-41.

27. Valik D, Radina M, Sterba J, Vojtesek B. Homocysteine: Exploring its potential as a pharmacodynamic biomarker of antifolate chemotherapy. Pharmacogenomics. 2004;5:1151-1162. 
28. Kubota M, Nakata R, Adachi S, et al. Plasma homocysteine, methionine and S-adenosylhomocysteine levels following high-dose methotrexate treatment in pediatric patients with acute lymphoblastic leukemia or Burkitt lymphoma: Association with hepatotoxicity. Leuk Lymphoma. 2014;55:1591-1595.

29. Tufekci O, Yilmaz S, Karapinar TH, et al. A rare complication of intrathecal methotrexate in a child with acute lymphoblastic leukemia. Pediatr Hematol Oncol. 2011;28:517-522.

30. Seshadri S, Wolf PA, Beiser AS, et al. Association of plasma total homocysteine levels with subclinical brain injury: Cerebral volumes, white matter hyperintensity, and silent brain infarcts at volumetric magnetic resonance imaging in the Framingham Offspring Study. Arch Neurol. 2008;65:642-649.

31. Bottiglieri T. Homocysteine and folate metabolism in depression. Prog Neuropsychopharmacol Biol Psychiatry. 2005;29:1103-1112.

32. Haagsma $\mathrm{CJ}$, Blom $\mathrm{HJ}$, van Riel $\mathrm{PL}$, et al. Influence of sulphasalazine, methotrexate, and the combination of both on plasma homocysteine concentrations in patients with rheumatoid arthritis. Ann Rheum Dis. 1999;58:79-84.

33. Crider KS, Yang TP, Berry RJ, Bailey LB. Folate and DNA methylation: A review of molecular mechanisms and the evidence for folate's role. Adv Nutr. 2012;3:21-38.

34. Ientile R, Curro' M, Ferlazzo N, Condello S, Caccamo D, Pisani F. Homocysteine, vitamin determinants and neurological diseases. Front Biosci (Schol Ed). 2010;2:359-372.
35. Papatheodorou L, Weiss N. Vascular oxidant stress and inflammation in hyperhomocysteinemia. Antioxid Redox Signal. 2007;9:1941-1958.

36. Goyette $P$, Sumner JS, Milos R, et al. Human methylenetetrahydrofolate reductase: Isolation of CDNA, mapping and mutation identification. Nat Genet. 1994;7:195-200.

37. Kim YI. Folate and carcinogenesis: Evidence, mechanisms, and implications. J Nutr Biochem. 1999;10:66-88.

38. Yamada K, Chen Z, Rozen R, Matthews RG. Effects of common polymorphisms on the properties of recombinant human methylenetetrahydrofolate reductase. Proc Natl Acad Sci USA. 2001;98: 14853-14858.

39. Robien K, Ulrich CM. 5,10-methylenetetrahydrofolate reductase polymorphisms and leukemia risk: A HuGE minireview. Am J Epidemiol. 2003;157:571-582.

40. Fisher MC, Cronstein BN. Metaanalysis of methylenetetrahydrofolate reductase (MTHFR) polymorphisms affecting methotrexate toxicity. J Rheumatol. 2009;36:539-545.

41. Yang L, Hu X, Xu L. Impact of methylenetetrahydrofolate reductase (MTHFR) polymorphisms on methotrexate-induced toxicities in acute lymphoblastic leukemia: A meta-analysis. Tumour Biol. 2012; 33:14451454. 